\title{
KAVUN ÇEKİRDEĞİ TOZUNUN ERİŞTENİN BAZI ÖZELLİKLERİNE ETKİSİ
}

\author{
İlyas Çelik*, Kübra Pozan \\ Pamukkale Üniversitesi, Mühendislik Fakültesi, Gıda Mühendisliği Bölümü, Denizli, Türkiye
}

Geliş / Received: 08.03.2020; Kabul / Accepted: 31.08.2020; Online bask1 / Published online: 11.09.2020

Çelik, İ., Pozan, K. (2020). Kavun çekirdeği tozunun eriştenin bazı özelliklerine etkisi. GIDA (2020) 45(5) 907-916 doi: 10.15237/gida.GD20038.

Celik, I., Pozan, K. (2020). The effect of melon seed powder on some properties of noodle. GIDA (2020) 45(5) 907916 doi: $10.15237 /$ gida.GD20038.

\section{ÖZ}

Bu çalışmada, kavun çekirdeği tozunun farklı ikame oranlarında (\%10, \%20, \%30 ve \%40) kullanılarak üretilen eriştelerin diyet lifi, yağ, mineral, protein içeriklerinin artırılması, atık değerlendirmenin öneminin vurgulanması ve eriştenin fonksiyonel özelliklerinin artırılması amaçlanmıștır. Kontrol eriștelere göre kavun çekirdeği tozu ilavesi ile elde edilen eriştelerde protein (\%12,34-16,71), toplam diyet lifi (\%4,03-10,17), yağ $(\% 3,76-19,12)$ ve mineral içeriklerinde önemli artışlar gözlemlenmiştir. Kavun çekirdeği tozu eriştelerin parlaklık değerlerini düşürmüş, kırmızılık ve sarılık değerlerini artırmıştır. Kavun çekirdeği tozu oranı arttıkça suya geçen madde miktarı artmıştır. Eriştelerde renk, koku, tekstür, lezzet ve genel beğeni anlamında en yüksek puanı kontrol örneği alırken en düşük puanı $\% 40$ kavun çekirdeği tozu katkılı erişteler almıştır. Uygulama içinde en fazla beğenilen \%10 kavun çekirdeği tozu içeren formülasyon olmuştur.

Anahtar kelimeler: Kavun çekirdeği, erişte, diyet lifi, tekstür, mineral madde.

\section{THE EFFECT OF MELON SEED POWDER ON SOME PROPERTIES OF NOODLE}

\begin{abstract}
In this study, it is aimed to increase the dietary fiber, fat, mineral and protein contents of the noodles produced by the use of melon seed powder (MSP) in different levels $(10 \%, 20 \%, 30 \%$ and $40 \%$ ), to emphasize the importance of waste assessment and to give functional properties to the noodle. With the addition of MSP compared to control noodles, protein (12.34-16.71\%), total dietary fiber (4.03$10.17 \%)$, fat (3.76-19.12\%) and mineral content of noodles changed significantly. The use of MSP decreased the brightness of the noodles but increased the redness and yellowness color values. As the level of MSP increases, the amount of substance passing into the water was increased. The highest score for noodles in terms of sensorial properties were observed in control, while the lowest score is $40 \%$ MSP added noodles. The most desired formulation in the application was the formulation containing 10\% MSP.
\end{abstract}

Keywords: Melon seed, noodle, dietary fiber, texture, mineral substance.

\footnotetext{
* Yazışmalardan sorumlu yazar/ Corresponding author 


\section{GİRIŞ}

Canlıların yaşamlarını sürdürebilmek için gereksinim duyduğu temel ihtiyaçlarının başında enerji gelmektedir. İnsanlar, vücutlarında kullandıkları enerjiyi tükettikleri bitkisel ve hayvansal besin kaynaklarından rahatlikla temin edebilmektedirler (Aktaş, 2012). İnsanların enerji kaynağı olarak kullandığı bitkisel besin kaynakları arasinda tahıl ve tahıl ürünleri önemli bir yere sahiptir (Kalkan ve Özarı, 2017). Kolay elde edilebilir olması ve maliyetinin düşük olması tahıllarin en ucuz enerji kaynağı olduğunu doğrulamaktadır. (Şahin, 2001). Tahıl ürünleri içerisinde en çok bilinen karbonhidrat kaynakları başta ekmek olmak üzere makarna, erişte, tarhana, çeşitli fırıncllık ve pastacılık ürünleridir (Eyidemir, 2006).

Erişte, tahıl ürünleri arasında geleneksel olarak üretilip ve sevilerek tüketilen bir ürün grubudur. Bölgeden bölgeye gerek kullanılan hammadde gerekse yapılış biçimine bağlı olarak farklılıklar gösterebilmektedir (Gulia vd, 2014). Eriştenin hızlı ve kolay pişirilmesi, düşük maliyeti, besleyiciliğinin yüksek olması, kurutulmuş ürün olmasına bağlı olarak raf ömrünün uzun olması gibi avantajlanı sayesinde üretim ve tüketimi yaygın bir şekilde yapılmaktadır. Erişte yapısında yüksek oranda karbonhidrat bulundurmasina rağmen protein miktarı ve aminoasit dengesi bakımından zayıflık gösterebilmektedir (Öncel, 2017). Bu durumun da eriştenin zenginleştirilmesi ve fonksiyonelliğinin artırılmasına yönelik çalışmaların ortaya çıkmasına yol açtı̆̆ görülmektedir. $\mathrm{Bu}$ amaçla yapılan çalışmaların temel amacı ürünün kimyasal yapısını geliştirmek, farklı formlarda yeni ürünler üretmek, ürünün besin değerini artırmaktır (Eyidemir, 2006). Üründe iyileştirmeler yapılırken doğadan ilham alınarak çeşitli bitkiler ve bitkisel atıklar kullanılmaktadır. Bitkisel atık olarak nitelendirilen meyve ve sebze atıkları beslenme açısından önemli olan diyet lifi, antioksidanlar, önemli yağ asitleri, vitaminler gibi birçok faydalı bileşenleri yapılarında bulundurmaktadırlar. Atıkların ürün bünyesinde değerlendirilmesi ile bu maddelerin kazanımı sağlanabilmektedir (Yağcı vd, 2006).
$\mathrm{Bu}$ çalışmada atık durumda bulunan kavun çekirdeğin kullanım alanını geliştirmede kavun çekirdeğinin kendine özgü özelliklerin erişteye aktarılması ve eriştenin fonksiyonel özelliklerinin artırılması amaçlanmışır.

\section{MATERYAL VE METOD \\ Kavun Çekirdeği Tozu Üretimi}

Tunceli ve Elazı̆ bölgesinde yetişen kavungillerden olan kultik (kır kavunu) kavunun çekirdeğin tozu erişte üretiminde kullanılmıştır. Çekirdek açı renkli ve ince kabuklu bir yapiya sahiptir. Kuru formda olan kavun çekirdekleri temizleme işlemi sonrasinda taş öğütücü kullanılarak öğütme işlemi gerçekleştirilmiştir. Homojen kavun çekirdeği tozu elde etmek için $500 \mu \mathrm{m}$ tel elekten geçirilmiştir. Erişte üretim anına kadar elde edilen kavun çekirdek tozu buzdolabı şartlarında tutulmuştur.

\section{Erişte Üretimi}

Çalışma erişte üretimi için uygun olan özel amaçlı buğday ununa ikame oranlarına göre diğer hammaddeler karıştırilarak uygun deneme planı oluşturulmuştur. 2 tekerrürlü olarak yapılmıştır (Çizelge 1). Formülasyona göre kontrol örneği için $100 \mathrm{~g}$ un, $20 \mathrm{~g}$ yumurta, $0,5 \mathrm{~g}$ tuz ve $36 \mathrm{~mL}$ su kullanılmıştır (Bilgiçli, 2009).

Erişte üretimi için belirlenen miktarlarda tartılan hammaddeler karıştırilıp öncelikle yoğurucunun (KMM060 Mutfak Şefi, Kenwood) düşük hız ayarında 1 dakika sonrasında yoğurucu hızı artırilarak 5 dakika yoğurulmuştur. Yoğrulan hamurlar hamurun işlenmesini kolaylaştırmak amacıyla 20 dakika dinlendirilmiştir. Sonrasında eşit parçalara ayrrlan hamurlar öncelikle merdane yardimiyla inceltme makinasına uygun olacak şekilde açılmıştır. Hamur yoğurucunun açma aparatı ile makinada önce geniş aralıkta sonra daha dar olan aralıkta eşit hızda açılmıştır. Açılan hamurlar oda koşullannda $\left(24{ }^{\circ} \mathrm{C}\right)$ yaklaşı 10 dakika daha dinlendirilip eriştelerin hamurlarının $5 \mathrm{~mm}$ genişliğinde $2 \mathrm{~mm}$ kalınlığında şeritler halinde kesilmeleri sağlanmıştır. Hamurlar bıçak yardımı ile kesilerek yağlı kâğıt serilen tepsilere özenle birbirine yapışmayacak şekilde \%10 su içeriğin altına düşünceye kadar oda şartlarında kurutulmuştur. 
Çizelge 1.Farklı oranlarda kavun çekirdeği tozu kullanılarak hazırlanan erişte formülasyonları Table 1. Noodle formulations prepared using melon seed powder in different proportions

\begin{tabular}{|c|c|c|c|c|c|}
\hline & $\begin{array}{l}\text { Kontrol } \\
\text { Control }\end{array}$ & $\% 10$ & $\% 20$ & $\% 30$ & $\% 40$ \\
\hline $\begin{array}{l}\text { Buğday unu }(\mathrm{g}) \\
\text { Wheat flour }(g)\end{array}$ & 100 & 90 & 80 & 70 & 60 \\
\hline $\begin{array}{l}\text { Kavun çekirdeği tozu }(\mathrm{g}) \\
\text { Powder melon seed }(\mathrm{g})\end{array}$ & 0 & 10 & 20 & 30 & 40 \\
\hline $\begin{array}{l}\text { Yumurta }(g) \\
\text { Egg }(g)\end{array}$ & 20 & 20 & 20 & 20 & 20 \\
\hline $\begin{array}{l}\text { Tuz }(g) \\
\text { Salt }(g)\end{array}$ & 0,5 & 0,5 & 0,5 & 0,5 & 0,5 \\
\hline $\begin{array}{l}\mathrm{Su}(\mathrm{mL}) \\
\text { Water }(m L)\end{array}$ & 36 & 31 & 28 & 24 & 21 \\
\hline
\end{tabular}

\section{Hammadde ve Eriştelerde Yapılan Analizler}

Hammadde ve erişte örneklerinin nem miktarları AACC 44-19, kül miktar1 tayini AACC 08-01, protein tayini AACC 46-12 metodu esas alınarak kjeldahl yöntemine göre yapilmıştır. Azot çevirici faktör 5.70 olarak hesaplanmıştır. Ham yağ miktar1 tespitinde ise AACC 30-25 metodundan faydalanılmıştır (AACC, 1999).

Mineral analizi için $0.5 \mathrm{~g}$ tartılan numunelere 10 $\mathrm{mL} \mathrm{HNO}_{3}$ eklenerek mikrodalga cihazında yaş yakma işlemi gerçekleştirilmiştir. Sonrasında örnekler $50 \mathrm{~mL}$ 'lik balon jojeye alınarak mavi bant filtre cihazından süzülmüss ve geri kalan hacim saf su ile tamamlanmıştır. Elde edilen süzüntüler ICP-OES cihazına verilerek element miktarları tespit edilmiştir (Kaçar ve İnal, 2008).

Buğday unu, kavun çekirdeği tozu ve erişte örneklerinde yapılan diyet lifi analizleri a-amilaz, proteaz ve amiloglikozidaz enzimlerini içeren toplam diyet lifi analiz kiti (Megazyme International Ireland Ltd, Wicklow, Ireland) kullanılarak yapılmıştır. Sindirilebilir nişastanın hidrolizi ve jelatinizasyonu için örneklere sırasıyla enzim ilavesi yapılmıştır. Her bir örnek karışım Gooch krozesinden (sinter cam filtreli, $30 \mathrm{~mL}$, 1D, Por: 4) vakum pompasiyla filtre edilerek filtrenin üzeri saf su ile yıkanmış ve filtrat uzaklaştırıp üzerine yaklaşı dört katı kadar 60 ${ }^{\circ}$ C'deki etanol eklenerek, çözünür diyet lifi analizinde kullanılmak üzere bir saat oda koşullarında bekletilmiştir. Filtrat uzaklaştırıldıktan sonra kalan kısım \%95'lik etanol ve asetonla tekrar y1kanmıştır. Çözünmeyen diyet lifini oluşturan bu kısım, aynı zamanda analizin sonrasında yapılacak protein ve kül analizlerinde belirlenecek sindirilemeyen protein ve çözünmeyen mineralleri de bulundurmaktadır. Bir saat oda koşullarında bekletilip çözünür diyet lifinin çöktürülmesi sağlanan çökelti tekrar Gooch krozesinden vakumla filtre edilmiş, $\% 78$ ve \%95'lik etanol ve asetonla yıkanmışır. Bu kısım da çözünür diyet lifini oluşturmakta aynı zamanda sindirilemeyen protein ve mineralleri de içermektedir. Elde edilen çözünür ve çözünmeyen diyet lifini içeren kalıntılar $103 \pm 2{ }^{\circ} \mathrm{C}$ 'de etüvde 12 saat bekletilmiş ve tartıldıktan sonra içerisindeki protein ve minerallerin hesaplanması için protein ve kül analizleri yapılmıştır. Elde edilen verilerle çözünür ve çözünmeyen diyet lifi miktarlar1 ayrı ayrı hesaplanmıştır (Tümer, 2017).

Hammadde (buğday unu ve kavun çekirdeği tozu) ve üretilen erişte örneklerinin renk analizleri Hunter LabScan Colorimeter (HunterLab MiniScan XE, Amerika) cihaz1 kullanilarak yapılmıstır. Renk özellikleri olarak L (koyulukparlaklık), a (+kırmızı, -yeşil) ve b (+sarı, -mavi) değerleri saptanmıştır (Elgün vd, 2012).

Eriştelerin tekstür özellikleri Brookfield Model No: CT3-4500 tekstür analiz cihazında hem erişte hamurları hem de pişmiş eriştelerde yapılmıştır. Erişte hamurları ile eriştelerde ayrı ayrı sertlik ve çekme özellikleri belirlenmiştir. Sertlik özelliklerini belirlemek için erişte hamurları 5 $\mathrm{cmx} 10 \mathrm{~cm}$, çekme değerini belirlemek için 2.5 
cmx10 cm olacak şekilde kesilmiştir. Çalı̧ma şartları sıkıştırmada TA-DE probu, hedef değer $0,4 \mathrm{~mm}$, tetikleme yükü $0.05 \mathrm{~N}$ test hizı 0.5 $\mathrm{mm} / \mathrm{s}$, çekme testinde ise TA-DGF probu, hedef değer $20.0 \mathrm{~mm}$, tetikleme yükü $0.05 \mathrm{~N}$ test hız1 2 $\mathrm{mm} / \mathrm{s}$ şartlarında yapılmıştır

Erişte örneklerinin ağırlık artışı belirlenirken $10 \mathrm{~g}$ erişte örneği $250 \mathrm{~mL}$ saf suda su banyosu içerisinde 15 dakika pişirilmiştir. Süzülüp yaklaşık 2 dakika dinlendirilen erişteler tartılmıştır. Eriştelerin pişirme öncesi ve pişirme sonrası ağırlıkları dikkate alınarak ağırlık artışı \% olarak hesaplanmıştır. Hacim artışını belirlemek için öncelikle $10 \mathrm{~g}$ olarak tartılan erişte örnekleri için saf su dolu ölçü silindirine koyularak ölçü silindirine karşılık gelen değer yani eriştelerin taşırdığı su miktarı belirlenmiş sonrasında yine ağırlık artışında olduğu gibi pişirilip süzülen erişte örnekleri dinlendirildikten sonra ölçü silindirine alınmıș ve tekrar taşırdığı su miktarı kaydedilmiștir. Pișirme sonrası ve pișirme öncesi değerin farkı alınarak \% olarak hacim artışı hesaplanmıştır (Özkaya ve Özkaya, 2005; Aktaş, 2012). Suya geçen madde miktarı tayininde ise erişte örnekleri $10 \mathrm{~g}$ olacak şekilde tartılarak içerisinde $250 \mathrm{~mL}$ su bulunan 500-600 mL'lik beherlere alınmıştır. Beherler sıcaklığ $98 \pm 2{ }^{\circ} \mathrm{C}$ 'ye ayarlanmış su banyosunda yaklaşık 18 dakika pişirilmiştir. Pişirme sonrasında erişteler porselen süzgeçler yardımı ile süzülmüştür. İçinde süzüntü bulunan beherler $135^{\circ} \mathrm{C}$ 'deki etüve koyularak bir gece boyunca kurumaları sağlanmıştır. Tartılan beherlere göre suya geçen kuru madde miktarları hesaplanmıştır (Aktaş, 2012).

Eriştelerin renk, koku, lezzet, tekstür ve genel beğeni özelliklerinin değerlendirmesi amacıyla yapilan duyusal analiz için Gıda Mühendisliği Bölümü öğrencileri ve öğretim elemanlarından oluşan 20 kişilik panelist grubu belirlenmiştir. Panelistlerin yaş aralığ 20-50 olarak belirlenmiştir. Erişte örnekleri kodlanan rastgele numaralarla panelistlere sunulmuş ve panelistlerden 1 (Aşırı kötü) - 7 (Mükemmel) olacak şekilde değerlendirme yapmaları istenmiştir (OnoğurAltuğ ve Elmac1, 2015).
Araştırma sonuçlan IBM SPSS statistics 22 programı kullanılarak tek yönlü varyans analizi (ANOVA) ile değerlendirilmiştir. Farklar önemli bulunduğunda ortalamalar Duncan testi kullanılarak karşılaştırılmıştır (Arbuckle, 2014).

\section{BULGULAR VE TARTIŞMA}

\section{Eriştelerin Kimyasal Özelliklerinin}

\section{Belirlenmesi}

Eriştelerin nem içeriklerinde en yüksek değerin kontrol örneğinde görülmüştür (Çizelge 2). Kavun çekirdeği tozu ilave oranı arttıkça nem değerinde azalma görülmesine karşın istatistiksel olarak önemli bulunmamıştır Kavun çekirdeği tozu katkısına bağlı olarak nem miktarının azalmasını yă̆ oranı yüksek olan bileșenlerin düşük oranlarda hidrofilik bileşikler içermesinden dolayı artan yağ içeriğine bağlayabiliriz (Manthey vd, 2004). Erişte yapımında keten tohumun kullanıldığı bir çalışmada keten tohumu ilavesiyle nem oranlarında önemli bir azalma gözlemlenmiştir (Yüksel vd, 2018).

Eriştelerin kül içerikleri kavun çekirdeği tozu ilavesine bağlı olarak artmıştır. Kavun çekirdeği tozu ve kullanılan özel amaçlı undaki kül oranları sıras1 ile $\% 3.65$ ve $\% 0.45$ olarak belirlenmiştir. Üretilen eriştelerde kül miktarının ise bu iki değer aralı̆̆ında olması beklenir. Beklendiği gibi eriştelerde kül oranının buğday unundaki kül oranıla mukayese edildiğinde 2.28 ile 4.17 kat arasında arttı̆̆1 görülmektedir (Çizelge 2). Kavun çekirdeği tozundaki yüksek mineral içeriği eriştelerin kül miktarındaki artışın oluşmasında etkili olmuştur.

Kavun çekirdeğinin yağ içeriğinin oldukça fazla olduğu yapılan birçok çalışmalardan anlaşılmaktadır (Melo vd,.2000; Petkova ve Antova, 2009). Çalışmada kullanılan özel amaçlı buğday ununun yağ içeriği \%1.56 olarak belirlenmiştir (Çizelge 2). Üretilen eriştelerin yă̆ oranları ise \%3.76 ile \%19.12 arasında değiştiği gözlenmiştir Kontrol örneğine kiyasla \%10 kavun çekirdeği tozu ilavesi ile üretilen eriştelerde 2.15 kat artarken \%40 kavun çekirdeği tozu ilave edilen örnekte 5,08 kat artmıştır. Kavun çekirdeği tozu yüksek orandaki yağ içeriği ile $(\% 45,59)$ üretilen eriştelerin yağ içeriğini önemli düzeyde artırmıştır. 
Çizelge 2. Hammadde ve erişte kimyasal analiz sonuçları

Table 2.Chemical analysis results of raw materials and noodles

\begin{tabular}{|c|c|c|c|c|c|c|c|}
\hline & $\begin{array}{c}\text { Buğday } \\
\text { unu } \\
\text { Wheat flour }\end{array}$ & $\begin{array}{c}\text { Kavun } \\
\text { çekirdeği tozu } \\
\text { Powder melon } \\
\text { seed }\end{array}$ & $\begin{array}{l}\text { Kontrol } \\
\text { Control }\end{array}$ & $\% 10$ & $\% 20$ & $\% 30$ & $\% 40$ \\
\hline $\begin{array}{l}\text { Nem(\%) } \\
\text { Moisture(\%) }\end{array}$ & $10,31 \pm 0,93$ & $4,25 \pm 0,06$ & $9,10 \pm 0,7^{a}$ & $8,63 \pm 0,8^{a}$ & $8,34 \pm 0,8$ a & $7,93 \pm 1,1^{\text {a }}$ & $7,51 \pm 1,2$ a \\
\hline $\begin{array}{l}\mathrm{Kül}(\%) \\
A s h(\%)\end{array}$ & $0,45 \pm 0,01$ & $3,65 \pm 0,39$ & $0,85 \pm 0,44 \mathrm{c}$ & $1,03 \pm 0,65 c$ & $1,34 \pm 0,48 \mathrm{~b}$ & $1,57 \pm 0,17 \mathrm{~b}$ & $1,88 \pm 0,07$ a \\
\hline $\begin{array}{l}\text { Yağ(\%) } \\
\text { Fat }(\%)\end{array}$ & $1,55 \pm 0,26$ & $45,59 \pm 0,13$ & $3,76 \pm 1,07 \mathrm{e}$ & $8,10 \pm 0,18 \mathrm{~d}$ & $11,81 \pm 1,40^{c}$ & $16,47 \pm 0,40 \mathrm{~b}$ & $19,12 \pm 0,01 \mathrm{a}$ \\
\hline $\begin{array}{l}\text { Protein }(\%) \\
\text { Protein }(\%)\end{array}$ & $10,37 \pm 1,28$ & $23,13 \pm 1,64$ & $12,34 \pm 0,56^{b}$ & $13,51 \pm 1,46 \mathrm{ab}$ & $14,57 \pm 1,41 \mathrm{ab}$ & $15,86 \pm 1,67 \mathrm{ab}$ & $16,71 \pm 0,96 \mathrm{a}$ \\
\hline $\begin{array}{l}\text { Çözünür diyet lifi (\%) } \\
\text { Soluple diatery }(\%)\end{array}$ & $1,09 \pm 0,07$ & $3,05 \pm 0,69$ & $1,19 \pm 0,07 \mathrm{~b}$ & $1,22 \pm 0,16 \mathrm{~b}$ & $1,34 \pm 0,09 \mathrm{ab}$ & $1,57 \pm 0,12$ a & $1,63 \pm 0,24$ a \\
\hline $\begin{array}{l}\text { Çözünmez diyet lifi (\%) } \\
\text { Insoluple diatery }(\%)\end{array}$ & $1,49 \pm 0,05$ & $27,08 \pm 0,84$ & $2,84 \pm 0,11^{\mathrm{c}}$ & $3,99 \pm 0,40^{c}$ & $5,73 \pm 0,22 \mathrm{~b}$ & $6,53 \pm 0,44 \mathrm{ab}$ & $8,54 \pm 0,79$ a \\
\hline $\begin{array}{l}\text { Toplam diyet lifi }(\%) \\
\text { Total diatery }(\%)\end{array}$ & $2,58 \pm 0,15$ & $30,13 \pm 1,48$ & $4,03 \pm 0,18 c$ & $5,21 \pm 0,57 \mathrm{c}$ & $7,07 \pm 0,31 \mathrm{~b}$ & $8,10 \pm 0,57$ b & $10,17 \pm 1,03^{a}$ \\
\hline
\end{tabular}

Parametreler kuru madde üzerinden verilmiștir, Protein 5,70 faktörü ile hesaplanmıștır,

Parameters are given on dry matter, Protein is calculated with a factor of 5.70 ,

Satırda aynı harfle gösterilenler istatiksel açıdan önemsizdir $(P<0.05)$.

Those shown with the same letter on the line are statistically insignificant $(P<0.05)$.

Eriştelerin içerdikleri protein oranlarına bakı1dığında en yüksek miktarı \%40 kavun çekirdeği tozu içeren örnekte, en düşük protein miktar1 ise kontrol örneğinde belirlenmiştir. Buğday unu kullanılarak üretilmiş olan kontrol eriştelerde buğday ununa göre protein miktarındaki artış 1.18 kat olurken, kavun çekirdeği tozu ilavesine bağlı olarak en yüksek değişim \%40 ilaveli örnekte 1,61 kat arttığ1 gözlemlenmiştir.

Üretilen kavun çekirdeği tozu katkılı eriştelerin çözünür, çözünmez ve toplam diyet lifi analiz sonuçlar1 Çizelge 2'de verilmiştir. Çözünür ve çözünmez olarak iki farklı grupta incelenen diyet lifi miktarlarına bakıldığında genel anlamda çözünmez diyet liflerinin çözünür diyet liflerine göre toplam diyet lifi içerisinde daha büyük paya sahip oldukları görülmektedir. Çözünmeyen diyet liflerinin (selüloz, hemiselüloz, lignin) yüksek yağ tutma kapasiteleri sayesinde gidalarda lezzetinin korunması ve gıdaların teknolojik özelliklerinin artırılması, gidaların kalori değerlerinin düşürülmesi gibi etkilerine ilaveten, ağırllğının yaklaşık 20 katı kadar suyu absorbe edebilen bir posa olarak boşaltım sistemi ile atılarak bağırsakları rahatlatıc1 etkisi de söz konusudur. Kolayca fermente olabilen çözünür diyet liflerinin (gum maddeleri, pektin ile diğer jel benzeri polisakkaritler, $\beta$-glukan) ise fermentasyon neticesinde kısa zincirli yağ asitleri ile oluşturduğu çeşitli gazların $\left(\mathrm{CO}_{2}, \mathrm{H}_{2}, \mathrm{CH}_{4}\right)$ bağırsak pH' sını değiştirdiği ve istenmeyen şişkinlik hissine neden olduğu bilinmektedir (Burdurlu, 2003). Erişte örneklerinde kavun çekirdeği tozu miktarındaki artışa bağlı olarak çözünür, çözünmez ve toplam diyet lifi miktarlarında belirgin bir şekilde artmış, en düşük diyet lif değerleri kontrol örneğinde belirlenmiş, en yüksek değerler $\% 40$ kavun çekirdeği tozu kullanılan erişte örneklerinde belirlenmiştir. Erişte formülasyon kavun çekirdeği tozu katkısının artışı ile toplam diyet lifi miktarının artması kavun çekirdeğinin oldukça yüksek oranda lif içermesiyle açıklanabilir. Yapılan bir çalışmada kavun çekirdeğine ait diyet lifi oranını \% 25.32 olarak belirlemişlerdir (Mallek-Ayadi vd, 2018).

\section{Renk Analizleri}

Hammadde ve üretilen kavun çekirdeği tozu içeren erişte hamurlarındaki renk analiz sonuçlarına ait L, a, b renk değerleri Çizelge 3'de verilmiştir. Kontrol örneği ile kavun çekirdeği tozu içeren erişte karşılaştırıldığında ise kavun çekirdeği tozu ilavesi ile erişte örneklerinin L değeri azalırken, a (kırmızılık) ve b (sarllık) renk değerleri artış göstermiştir. b renk değerlerinin artışında kavun çekirdeği tozunun kendine özgü sar1 rengini veren karatenoidler etkili olduğu düșünülmektedir. 
Çizelge 3. Hammadde ve erişte renk analiz sonuçları

Table 3 . Color analysis results of raw materials and noodles

\begin{tabular}{lccc}
\hline Hammaddeler & $\mathrm{L}$ & $\mathrm{a}$ & $\mathrm{b}$ \\
\hline $\begin{array}{l}\text { Buğday unu } \\
\text { Wheat flour }\end{array}$ & $71,728 \pm 0,04$ & $0,073 \pm 0,01$ & $8,410 \pm 0,03$ \\
\hline $\begin{array}{l}\text { Kavun çekirdeği tozu } \\
\text { Powder melon seed }\end{array}$ & $56,080 \pm 0,19$ & $1,360 \pm 0,01$ & $13,010 \pm 0,04$ \\
\hline $\begin{array}{l}\text { Erişte } \\
\text { Noodles }\end{array}$ & $\mathrm{L}$ & $\mathrm{a}$ & $\mathrm{b}$ \\
\hline Kontrol & $54,86 \pm 0,25 \mathrm{a}$ & $1,81 \pm 0,69 \mathrm{~b}$ & $16,45 \pm 0,84 \mathrm{~b}$ \\
Control & $53,76 \pm 0,36 \mathrm{ab}$ & $2,04 \pm 0,34$ ab & $16,47 \pm 1,08 \mathrm{~b}$ \\
$\% 10$ & $52,29 \pm 1,23$ abc & $2,35 \pm 0,89$ a & $17,21 \pm 0,92$ a \\
$\% 20$ & $51,50 \pm 1,47 \mathrm{bc}$ & $2,33 \pm 0,45$ a & $17,22 \pm 0,60$ a \\
$\% 30$ & $50,56 \pm 0,13 \mathrm{c}$ & $2,56 \pm 0,52$ a & $17,76 \pm 0,58$ a \\
\hline 40 &
\end{tabular}

Sütunda aynı harfle gösterilenler istatiksel açıdan önemsizdir $(P<0.05)$.

Those shown with the same letter on the column are statistically insignificant $(P<0.05)$.

\section{Pişirme Analizleri}

Kontrol erişte örneklerinde su absorbsiyon değeri \%124,25 iken, kavun çekirdeği tozu içeren erişte formülasyonlarında kavun çekirdeği katkısına bağl1 olarak su absorbsiyon değerleri önemli düzeyde artmış ve \%171,87 değerine ulaşmıştır. Eriştelerin \%10 kavun çekirdeği tozu ilaveli örnek dışında aralarında istatistiksel anlamda önemli bir farka rastlanmamıştır (Çizelge 4). Hacim artış değerlerine bakıldığında su absorbsiyon değerlerine paralel şekilde bir artış olduğu görülmektedir. Kontrol erişte örneğinde $\% 124,16$ gibi bir değer gözlenirken \%40 kavun çekirdeği tozu içeren örnekte hacim artış1 \%153.05 olarak tespit edilmiştir. Örnekler arasında istatistiksel açıdan anlamlı bir fark gözlenmemiştir. Dirençli mısır nişastasının erişte formülasyonunda kullanıldığı çalışmada eriştelerinde pişirmeye bağlı hacim artıs değerlerini \%110,56 - \%150,19 olarak belirlemiştir (İnkaya Dündar, 2014). Yine benzer şekilde yulaf unu ilavesiyle üretilen eriştelerde kontrol örneğinde \% 135.29 hacim artış1 tespit edilirken \%40 yulaf unu kullandığı örnekte hacim artışını \%182.35 olarak belirlemiştir (Aydın, 2009). Pirinç kepeği ilavesinin erişte üretiminde kullanıldığ1 çalışmada pirinç kepeği ilavesinin artmasına bağlı olarak eriştelerin ağırlık ve hacim artış değerlerinin yükseldiği gözlemlenmiştir (Ertaş, 2014).Suya geçen kuru madde miktarı, eriştelerde pişirme sırasında suya geçen kuru madde miktarını belirtir. Suya geçen kuru madde miktarına pişirme kaybı da denebilmektedir. Sonuçlara bakıllığında artan kavun çekirdeği tozu oranı ile birlikte suya geçen madde miktarının da arttığ1 yönündedir. Bu durum artan ikame oranı ile gluten yapısının zayıflamasına bağlanabilir. Kontrol örneğinde suya geçen kuru madde miktar1 \%3.75 iken \%40 kavun çekirdeği tozu içeren formülasyonda \% $\% .72$ ulaşmıştır. Benzer şekilde nohut unu ilavesi ile üretilen eriştelerde suya geçen kuru madde miktarları \%4.13 ile \% 8.20 aralığında değiştiği tespit edilmiştir (Demir, 2008).

Erişte örneklerinde belirlenen fosfor, potasyum, kalsiyum, magnezyum, demir, mangan, çinko ve bakır miktarları belirlenmiş, kavun çekirdeği tozu miktarındaki artışa bağlı olarak erişte örneklerinin mineral içeriğinin arttığı gözlemlenmiştir (Çizelge 5). Erişte örneklerinin mineral madde miktarlarındaki bu artışa paralel olarak erişte örneklerin kül miktarları da artış göstermiştir (Çizelge 2). Çizelgede 5' te en fazla artış kontrol erişteye kıyasla Magnezyumda 5.37, fosforda 3.11 kat gerçekleşmiştir (Çizelge 5). Üretilen kavun çekirdeği tozu içeren eriştelerinin günlük mineral ihtiyacını karşılamada önemli bir kaynak olabileceği düşünülmektedir.

\section{Tekstür Analizleri}

Eriştelere örneklerine ait tekstür analiz sonuçları Çizelge 6'da sunulmuştur. Erişte hamurlarının 
sertlik değerleri en yüksek kontrol örneğinde 0.06 $\mathrm{N}$ belirlenmiştir. Kavun çekirdeği tozu ilavesine bağlı olarak erişte örneklerinin sertlik değerleri azalmış, ancak sertlik değerindeki bu azalma istatistiksel anlamda önemli fark oluşturmamıştır.

Çekme kuvveti ölçümü yapılan çiğ eriştelerde kontrol örneğinde $0.088 \mathrm{~N}$ ve $\% 10$ kavun çekirdeği tozu katkılı eriştelerde $0.082 \mathrm{~N}$ belirlenirken $\% 20, \% 30$ ve $\% 40$ kavun çekirdeği tozu içeren örneklerde sirasıyla $0.069 \mathrm{~N}, 0.067 \mathrm{~N}$ ve $0.066 \mathrm{~N}$ olarak belirlenmiş, kavun çekirdeği tozu içeren erişte örneklerinin çekme kuvveti değerlerindeki bu azalma istatiksel açıdan önemli bulunmamıştır. Pişirilmiş erişte örneklerinde ise çekme kuvveti değerleri erişte formülasyonuna dahil olan kavun çekirdeği tozu artışına bağlı olarak azalma gözlemlenmiştir. Bu durumu artan kavun çekirdeği oranına bağlı olarak azalan glüten yapısının kısmi olarak azalması ve elastikiyetin azalmasında etkili olmuştur.

Çizelge 4. Eriştelere ait pişirme analiz sonuçları

Table 4. Cooking analysis results of noodles

\begin{tabular}{lccc}
\hline & $\begin{array}{c}\text { Su absorbsiyonu (\%) } \\
\text { Water absorbsion }(\%)\end{array}$ & $\begin{array}{c}\text { Hacim artiş1 }(\%) \\
\text { Volume increase }(\%)\end{array}$ & $\begin{array}{c}\text { Suya geçen kuru madde }(\%) \\
\text { Water passing dry matter }(\%)\end{array}$ \\
\hline $\begin{array}{l}\text { Kontrol } \\
\text { Control }\end{array}$ & $124,25 \pm 2,43^{\mathrm{c}}$ & $124,16 \pm 4,72^{\mathrm{b}}$ & $3,75 \pm 0,17 \mathrm{c}$ \\
$\% 10$ & $142,77 \pm 0,01^{\mathrm{b}}$ & $150,61 \pm 3,05^{\mathrm{a}}$ & $5,11 \pm 1,60 \mathrm{bc}$ \\
$\% 20$ & $162,05 \pm 1,57^{\mathrm{a}}$ & $152,67 \pm 0,49^{\mathrm{a}}$ & $6,96 \pm 0,32^{\mathrm{abc}}$ \\
$\% 30$ & $171,06 \pm 0,26^{\mathrm{a}}$ & $152,95 \pm 4,00^{\mathrm{a}}$ & $8,43 \pm 0,58 \mathrm{ab}$ \\
$\% 40$ & $171,87 \pm 9,35^{\mathrm{a}}$ & $153,05 \pm 3,96^{\mathrm{a}}$ & $9,72 \pm 1,11^{\mathrm{a}}$ \\
\hline
\end{tabular}

Sütunda aynı harfle gösterilenler istatiksel açıdan önemsizdir $(P<0.05)$.

Those shown with the same letter on the column are statistically insignificant $(P<0.05)$.

Çizelge 5. Hammadde ve eriştelere ait mineral madde analiz sonuçları (mg/100g)

Table 5. Mineral material analysis results of raw material and noodles $(\mathrm{mg} / 100 \mathrm{~g})$

\begin{tabular}{lcccccc}
\hline & $\begin{array}{c}\text { Kavun } \\
\text { çekirdeği tozu } \\
\text { Powder melon seed }\end{array}$ & $\begin{array}{c}\text { Kontrol } \\
\text { Control }\end{array}$ & $\% 10$ & $\% 20$ & $\% 30$ & $\% 40$ \\
\hline $\mathrm{P}$ & 967.50 & $147.70 \pm 0.01 \mathrm{e}$ & $216.95 \pm 1.76 \mathrm{~d}$ & $301.65 \pm 6.01 \mathrm{c}$ & $384.00 \pm 2.40 \mathrm{~b}$ & $460.10 \pm 2.12 \mathrm{a}$ \\
$\mathrm{K}$ & 711.00 & $220.00 \pm 0.01 \mathrm{e}$ & $255.00 \pm 4.24 \mathrm{~d}$ & $309.00 \pm 11.31 \mathrm{c}$ & $362.00 \pm 4.24 \mathrm{~b}$ & $411.00 \pm 1.41 \mathrm{a}$ \\
$\mathrm{Ca}$ & 128.87 & $81.54 \pm 0.01 \mathrm{~b}$ & $86.13 \pm 2.24 \mathrm{ab}$ & $86.63 \pm 1.15 \mathrm{ab}$ & $97.84 \pm 11.76 \mathrm{a}$ & $99.18 \pm 0.24 \mathrm{a}$ \\
$\mathrm{Mg}$ & 462.57 & $37.12 \pm 0.01 \mathrm{e}$ & $66.36 \pm 0.09 \mathrm{~d}$ & $114.32 \pm 1.23 \mathrm{c}$ & $159.85 \pm 1.22 \mathrm{~b}$ & $199.89 \pm 0.73 \mathrm{a}$ \\
$\mathrm{Fe}$ & 9.71 & $2.71 \pm 0.01 \mathrm{e}$ & $3.18 \pm 0.09 \mathrm{~d}$ & $3.63 \pm 0.25 \mathrm{c}$ & $4.20 \pm 0.11 \mathrm{~b}$ & $5.03 \pm 0.01 \mathrm{a}$ \\
$\mathrm{Mn}$ & 2.93 & $1.14 \pm 0.01 \mathrm{e}$ & $1.29 \pm 0.01 \mathrm{~d}$ & $1.46 \pm 0.01 \mathrm{c}$ & $1.62 \pm 0.01 \mathrm{~b}$ & $1.77 \pm 0.01 \mathrm{a}$ \\
$\mathrm{Zn}$ & 9.61 & $1.81 \pm 0.01 \mathrm{e}$ & $2.50 \pm 0.01 \mathrm{~d}$ & $3.24 \pm 0.01 \mathrm{c}$ & $4.05 \pm 0.25 \mathrm{~b}$ & $4.83 \pm 0.05 \mathrm{a}$ \\
$\mathrm{Cu}$ & 1.71 & $0.34 \pm 0.01 \mathrm{e}$ & $0.45 \pm 0.01 \mathrm{~d}$ & $0.60 \pm 0.01 \mathrm{c}$ & $0.70 \pm 0.01 \mathrm{~b}$ & $0.87 \pm 0.02 \mathrm{a}$ \\
\hline
\end{tabular}

Satırda aynı harfle gösterilenler istatiksel açıdan önemsizdir $(P<0.05)$.

Those shown with the same letter on the line are statistically insignificant $(P<0.05)$.

Çizelge 6. Eriştelere ait tekstür analiz sonuçları

Table 6. Texture analysis results of noodles

\begin{tabular}{lccc}
\hline & $\begin{array}{c}\text { Hamurda sertlik }(\mathrm{N}) \\
\text { Hardness in dough }(\mathrm{N})\end{array}$ & $\begin{array}{c}\text { Hamurda germe }(\mathrm{N}) \\
\text { Tension in dough }(\mathrm{N})\end{array}$ & $\begin{array}{c}\text { Pişmiş eriştede germe }(\mathrm{N}) \\
\text { Tension in cooked noodle }(\mathrm{N})\end{array}$ \\
\hline $\begin{array}{l}\text { Kontrol } \\
\text { Control }\end{array}$ & $0,060 \pm 0,01 \mathrm{a}$ & $0,055 \pm 0,01 \mathrm{a}$ & $0,390 \pm 0,01 \mathrm{a}$ \\
$\% 10$ & $0,057 \pm 0,01 \mathrm{a}$ & $0,054 \pm 0,01 \mathrm{a}$ & $0,318 \pm 0,03 \mathrm{ab}$ \\
$\% 20$ & $0,052 \pm 0,01^{\mathrm{a}}$ & $0,052 \pm 0,01 \mathrm{ab}$ & $0,284 \pm 0,01 \mathrm{ab}$ \\
$\% 30$ & $0,049 \pm 0,01^{\mathrm{a}}$ & $0,050 \pm 0,01 \mathrm{ab}$ & $0,196 \pm 0,12 \mathrm{ab}$ \\
$\% 40$ & $0,048 \pm 0,01 \mathrm{a}$ & $0,033 \pm 0,01 \mathrm{~b}$ & $0,118 \pm 0,01 \mathrm{~b}$ \\
\hline
\end{tabular}

Sütunda aynı harfle gösterilenler istatiksel açıdan önemsizdir $(P<0.05)$.

Those shown with the same letter on the column are statistically insignificant $(P<0.05)$. 


\section{Duyusal Değerlendirme}

Genel olarak erişte örneklerinde değerlendirilen bütün parametreler açısından kavun çekirdeği tozu içeren formülasyonlar kontrol erişte örneğine kıyasla panalistlerden daha düşük puanlar almı̧tır (Çizelge 7). Eriştelerin tekstür parametrelerinde en yüksek değerin 5.92 ile kontrol örneğinde olduğu en düşük değerin ise $\% 40$ kavun çekirdeği tozu katkılı eriştelerde olduğu tespit edilmiştir. Elde edilen sonuçlardan erişte örneklerimde kavun çekirdeği tozu oranı arttıkça tekstürün önemli ölçüde olumsuz yönde etkilendiği gözlemlenmiştir. Renk, koku, tekstür, lezzet ve genel beğeni anlamında en yüksek puanı kontrol örneği alırken en düşük puanı \%40 kavun çekirdeği tozu katkılı erişteler almıştır. \%10 katkılı eriştiler diğer ikame oranlarına göre kabul edilebilir sonuçlar alınmıştır.

Çizelge 7. Erişte duyusal analiz sonuçları

Table 7. Sensory analysis results of noodles

\begin{tabular}{|c|c|c|c|c|c|}
\hline & $\begin{array}{c}\text { Renk } \\
(1-7 \mathrm{P}) \\
\text { Color } \\
(1-7 P) \\
\end{array}$ & $\begin{array}{c}\text { Koku } \\
(1-7 \mathrm{P}) \\
\text { Odor } \\
(1-7 \mathrm{P})\end{array}$ & $\begin{array}{c}\text { Lezzet } \\
(1-7 \mathrm{P}) \\
\text { Taste } \\
(1-7 P) \\
\end{array}$ & $\begin{array}{l}\text { Tekstür } \\
(1-7 \text { P) } \\
\text { Texture } \\
(1-7 P) \\
\end{array}$ & $\begin{array}{c}\text { Genel beğeni } \\
(1-7 \mathrm{P}) \\
\text { Over all } \\
(1-7 \mathrm{P}) \\
\end{array}$ \\
\hline $\begin{array}{l}\text { Kontrol } \\
\text { Control }\end{array}$ & $5,81 \pm 0,01$ a & $5,67 \pm 0,03$ a & $5,62 \pm 0,03$ a & $5,92 \pm 0,01 \mathrm{a}$ & $6,21 \pm 0,01$ a \\
\hline$\% 10$ & $5,36 \pm 0,05^{b}$ & $5,17 \pm 0,01 \mathrm{~b}$ & $5,33 \pm 0,01 \mathrm{~b}$ & $5,23 \pm 0,01 \mathrm{~b}$ & $5,61 \pm 0,01 \mathrm{~b}$ \\
\hline$\% 20$ & $4,92 \pm 0,01 \mathrm{c}$ & $4,61 \pm 0,01 \mathrm{c}$ & $4,90 \pm 0,03 \mathrm{c}$ & $4,72 \pm 0,01^{c}$ & $4,85 \pm 0,01 \mathrm{c}$ \\
\hline$\% 30$ & $4,45 \pm 0,01 \mathrm{~d}$ & $4,82 \pm 0,01 \mathrm{~d}$ & $4,55 \pm 0,01 \mathrm{~d}$ & $4,56 \pm 0,01 \mathrm{~d}$ & $4,66 \pm 0,01 \mathrm{~d}$ \\
\hline$\% 40$ & $4,52 \pm 0,03^{d}$ & $4,28 \pm 0,01^{\mathrm{e}}$ & $4,28 \pm 0,01^{\mathrm{e}}$ & $3,96 \pm 0,01 \mathrm{e}$ & $4,00 \pm 0,03^{\mathrm{e}}$ \\
\hline
\end{tabular}

Sütunda aynı harfle gösterilenler istatiksel açıdan önemsizdir $(P<0.05)$.

Those shown with the same letter on the column are statistically insignificant $(P<0.05)$.

\section{SONUÇ}

Kavun çekirdeği tozunun erişte formülasyonuna dâhil edildiği bu çalışmada, bitkisel atık olarak nitelendirilen kavun çekirdeğinin değerlendirilmesi ve kavun çekirdeğindeki yağ, mineral elementler, protein, karbonhidrat ve lif zenginliğinin erişteye kazandırılması ile eriştenin fonksiyonelliğinin artırılması amaçlanmışır. Kavun çekirdeğinin erişte formülasyonunda kullanılması ile hem kavun üreticisi açısından yan ürünlerin değerlendirilmesi mümkün kilınabilecek hem de ürünü tüketen açısından besin maddelerince zengin bir ürüne sahip olunabilecektir. Kontrol erişteye göre $\% 40$ kavun çekirdeği tozu ilavesi sonucunda; hamur ve erişte tekstürel yapısı üzerinde direnci düşürücü etkide, protein, kül, yağ ve toplam diyet lif miktarında artma yönünde etkide bulunmuştur. Su absorbsiyonu, hacim artışı ve suya geçen kuru madde miktarını artırıcı, L değerini düşürücü etkisi olmuştur. Kavun çekirdeği tozu ilavesi eriştenin mineral madde varlığında P 3.11, K 1.86, Ca 1.21, Mg 5.37, Fe 1.84, Mn 1.55, Zn 2.66 ve $\mathrm{Cu} 2.55$ kat artışa neden olmuştur. Duyusal açıdan kontrol erişteye göre düşüş olmasına karşın \%10 kavun çekirdeği tozu seviyesine kadar erişte üretiminde kullanabileceği sonucuna varılmıştır.

\section{TEŞEKKÜR}

Bu çalışmayı 2017FBE057 proje numarası ile maddi olarak destekleyen Pamukkale Üniversitesi, Bilimsel Araştırma Projeleri Koordinasyon Birimi’ne teşekkür ederiz.

\section{ÇIKAR ÇATIŞMASI BEYANI}

Yazarlar, çıkar çatışması olmadığını beyan eder.

\section{YAZAR KATKILARI}

Tüm yazarlar makalenin yapilmasinda, yazılmasında ve yayınlanmasında eşit katkı sağlamışlardır. Yazarlar makalenin son halini okumuş ve onaylamı̧tır.

\section{KAYNAKLAR}

AACC (1999). General methods. In approved methods of the american association of cereal chemists', (Method 44-19, Method 08-01, Method 
30-25, Method 46-12). 11th ed. American Association of Cereal Chemists, Ic., St. Paul, MN., Aktaş, K. (2012). Sütçülük yan ürünleri ve $\beta$ glukan ilavesi ile eriştenin besinsel özelliklerinin artırılması üzerine bir çalışma, Yüksek Lisans Tezi, Selçuk Üniversitesi Fen Bilimleri Enstitüsü, Konya, 110 s.

Altuğ Onoğur, T., Elmac1, Y. (2015). Gıdalarda duyusal değerlendirme. Sidas Medya Ltd. Şti. İzmir.

Arbuckle J. L. (2014). IBM SPSS statistics 22 For Windows User's Guide. http://www.sussex.ac.uk /its/pdfs/SPSS_Amos_User_Guide_22.pdf.

Aydın, E. (2009). Yulaf katkısının eriştenin kalite kriterlerine etkisi. Yüksek Lisans Tezi, Uludağ Üniversitesi Fen Bilimleri Enstitüsü Gıda Mühendisliği Anabilim Dalı, Bursa. 63 s.

Bilgiçli, N. (2009). Effect of buckwheat flour on cooking quality and some chemical, antinutritional and sensory properties of erişte, Turkish noodle. Int J Sci Nutr. 60, 4. doi: 10.1080/09637480802446639.

Burdurlu H., S., Karadeniz F. (2003). Gidalarda diyet lifinin önemi, 3. G1da Mühendisliği Kongresi, Ankara.

Demir B. (2008). Nohut ununun geleneksel erişte ve kuskus üretiminde kullanım imkanları üzerine bir araştırma, Selçuk Üniversitesi Fen Bilimleri Enstitüsü G1da Mühendisliği Anabilim Dalı, Yüksek Lisans Tezi, Konya, 77 s.

Elgün, A., Certel, M., Ertugay, Z., Kotancilar, H. G. (2012). Tahıl ve Ürünlerinde Analitik Kalite Kontrolü ve Labaratuar Uygulama Kilavuzu, Atatürk Üniversitesi Ziraat Fakültesi Yayınlar1 No:335.

Ertaş, N. (2014). Reutilisation of rice byproduct: study on the effect of rice bran addition on physical, chemical and sensory properties of erişte. Qual Assur and Safety of Crops \& Foods, 6, (2) 249-255. doi: 10.3920/QAS2013.0252

Eyidemir, E. (2006). Kayısı çekirdeği ilavesinin eriştenin bazı kalite kriterlerine etkisi, Yüksek Lisans Tezi, İnönü Üniversitesi Fen Bilimleri Enstitüsü, Malatya, 84 s.
Gulia, N., Dhaka, V., Khatkar, B.S. (2014). Instant noodles: Processing, quality, and nutritional aspects, critical. Rev Food Sci Nutr, 54(10), 1386-1399. doi: 10.1080/10408398. 2011.638227.

İnkaya Dündar A. N. (2014). Yüksek amilozlu mısır nişastasından dirençli nişasta eldesi ve erişte üretiminde kullanımı, Doktora Tezi, Uludağ Üniversitesi Fen Bilimleri Enstitüsü, Bursa, 134 s.

Kaçar B., İnal A. (2008). Bitki analizleri. Nobel Yayınlar1 No:1241.

Kalkan, İ., Özarık, B. (2017). Tam buğday ekmeği ve sağlık üzerine etkileri, Aydın Gastronomy. (1), 37-46.

Mallek-Ayadi, S., Bahloul, N., Kechaou, N. (2018). Chemical composition and bioactive compounds of Cucumis melo L. seeds: Potential source for new trends of plant oils. Process Safety Environ Prot 113, 68-77. doi: 10.1016/j.psep.2017.09.016

Manthey, F. A., Yalla, S. R, Dick, T. J., Badaruddin M. (2004). Extrusion properties and cooking quality of spaghetti containing buckwheat bran flour, Cereal Chem, 81 (2) 232236.doi: 10.1094/CCHEM.2004.81.2.232

Melo M.L.S., Narain N., Bora P.S. (2000). Characterisation of Some Nutritional Constituents of Melon (Cucumis melo hybrid AF522) Seeds. Food Chem, 68:411-414. doi: 10.1016/S0308-8146(99)00209-5

Öncel, E. (2017). Erişte üretiminde farklı oran ve kombinasyonlarda karabuğday, amarant ve kinoa unlarının kullanım imkanları, Yüksek Lisans Tezi, Necmettin Erbakan Üniversitesi Fen Bilimleri Enstitüsü, Konya, 85 s.

Özkaya, H., Özkaya, B. (2005). Tahıl ve ürünleri analiz yöntemleri. Gida Teknolojisi Derneği Yayınları Yayın No: 31, Ankara, Türkiye, 157 s.

Petkova, Z., Antova, G. (2015). Proximate composition of seeds and seed oils from melon (Cucumis melo L.) cultivated in Bulgaria. Cogent Food \& Agri, 1, 1018779. doi.:10.1080/23311932. 2015.1018779 
Şahin, S. (2001) Türkiye 'de Misır Ekim Alanlarının Dağglımı ve Misır Üretimi, G.Ü. Gazi Eğitim Fakültesi Dergisi, 21 (1) 73-90.

Tümer, G. (2017). Lokma ve tulumba tatlis1 üretiminde kavurga unu kullanım imkânının araştırılması ve bazı karakteristik özelliklerin belirlenmesi, Yüksek Lisans Tezi, Pamukkale Üniversitesi Fen Bilimleri Enstitüsü, Denizli, 59 s.
Yağc1, S., Altan A., Göğüş, F., Maskan, M. (2006) Gıda atıklarının alternatif kullanım alanları, Türkiye 9. Gıda Kongresi; 24-26.

Yüksel F., Akdoğan H., Çağlar S. (2018). Keten tohumu ile zenginleştirilmiş eriştelerin, fizikokimyasal, duyusal, pişme özellikleri ve yağ asidi kompozisyonunun belirlenmesi, GIDA (2018) 43(2) 222-230. doi:10.15237/ gida.GD17051 